\title{
The Management of Used (Spent) Fuel and High Level Waste in South Africa
}

\author{
V. Maree ${ }^{1, *}$, A. Carolissen ${ }^{2}$ \\ ${ }^{1}$ National Nuclear Regulator (NNR), South Africa \\ ${ }^{2}$ National Radioactive Waste Disposal Institute (NRWDI), South Africa
}

Copyright $\bigcirc 2017$ by authors, all rights reserved. Authors agree that this article remains permanently open access under the terms of the Creative Commons Attribution License 4.0 International License

\begin{abstract}
As a country with a nuclear power program and radioisotope production facility, the Republic of South Africa (RSA) generates Used Nuclear Fuel (UNF) and radioactive waste through numerous activities. The cornerstone of South Africa's approach to addressing radioactive waste management is the Radioactive Waste Management Policy and Strategy for the Republic of South Africa. The Policy and Strategy serves as a national commitment to address radioactive waste management in a coordinated and cooperative manner and represents a comprehensive radioactive waste governance framework by formulating, in addition to nuclear and other applicable legislation, a policy and implementation strategy developed in consultation with all stakeholders. In accordance with the Policy and Strategy, final disposal is regarded as the ultimate step in the radioactive waste management process, although a stepwise waste management process is acceptable. Long-term storage of specific types of waste, such as High-Level Waste (HLW), long-lived waste and high activity disused radioactive sources, may be regarded as one of the steps in the management process. This paper presents the South African National Radioactive Waste Management Model with a description of: The radioactive waste management governance framework; the current HLW and UNF management, the management option and UNF strategies. Also the paper addresses consideration of the lessons learnt from the Fukushima accident and its impact on future radioactive waste management strategies and options, plans related to possible long term operation of the existing nuclear power plants, introduction of new nuclear power plants and public acceptance and challenges from anti-nuclear groups.
\end{abstract}

Keywords Used Nuclear Fuel, High Level Waste, South Africa's Management Strategies, Challenges

\section{Introduction}

The Republic of South Africa (RSA) recognizes the importance of the safe management of spent fuel and radioactive waste, for this reason the country is a contracting party to the International Atomic Energy Agency (IAEA) Joint Convention on the Safety of Spent Nuclear Fuel Management and Safety of Radioactive Waste Management [1]. The Joint Convention provides for the establishment and maintenance of a legislative and regulatory framework to govern the safety of spent fuel and radioactive waste management. South Africa fulfills its obligations under the Joint Convention by the establishment of a Radioactive Waste Management Policy and Strategy for the Republic of South Africa (RWMP\&S) [2] and has invited the IAEA to conduct the Integrated Nuclear Infrastructure Review (INIR) mission in 2013. The INIR mission has recommended that South Africa to develop an integrated national Nuclear Fuel Cycle strategy, including Used Nuclear Fuel (UNF)/High Level Waste (HLW) disposal [3]. South Africa already has in place a strong national radioactive waste management model and is considering different options and strategies to address the long term management of the UNF and HLW as recommended by the INIR.

\section{Background}

The past strategic programmes and the current nuclear programs contribute to the generation of HLW and UNF. HLW for legal and regulatory purposes, is defined as 'waste with levels of activity concentration high enough to generate significant quantities of heat $\left(>2 \mathrm{~kW} / \mathrm{m}^{3}\right)$, or waste with large amounts of long lived radionuclides'.

In 1991, South Africa signed the Nuclear Non-Proliferation Treaty and in 1993 voluntarily announced the dismantling of its nuclear weapons programme, HLW was generated from a historical nuclear programme. In the South African context, HLW doesn't include fuel coming from the irradiated fuel reactor cycle. The term "used fuel" is used instead of "spent fuel" because used fuel is considered to have useful material and is not classified as radioactive 
waste. UNF is produced in two main nuclear facilities: The South African Nuclear Energy Corporation (NESCA) and Koeberg Nuclear Power Station (KNPS). Necsa, located at Pelindaba $30 \mathrm{~km}$ west of Pretoria operates a 20 Megawatt tank-in-pool type nuclear research reactor: SAFARI-1 (Fig.2.). The research reactor has been in operation for 50 years and is used in the production of medical radioisotopes and nuclear research. KNPS is the only nuclear power plant in Africa and is comprised of 2 Framatome Power Water Reactors of 900 MWe each operated by the State Own Company Eskom. KNPS is in operation since 1984 and situated on the Atlantic coast, 40 kilometers north of Cape Town (Fig.2).

\section{South African Radioactive Waste Management Model}

The overarching objective of radioactive waste management is to deal with radioactive waste in a manner that protects human health and the environment now and in future without imposing undue burdens on the future generations.

\subsection{Radioactive Waste Management Governance Framework}

The following diagram depicts the governance framework for radioactive waste in RSA:

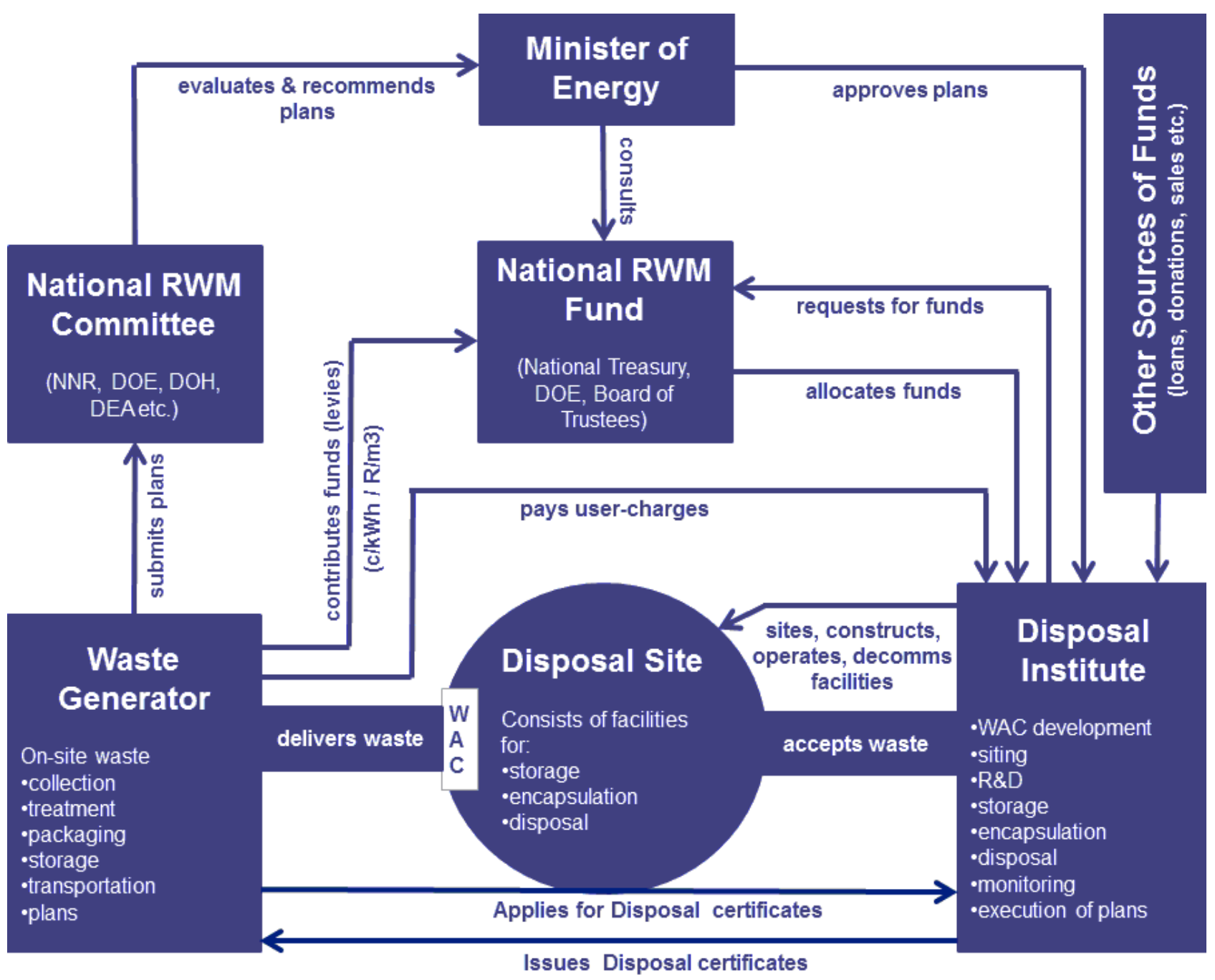

Figure 1. Schematic Governance Framework for Radioactive Waste Management 


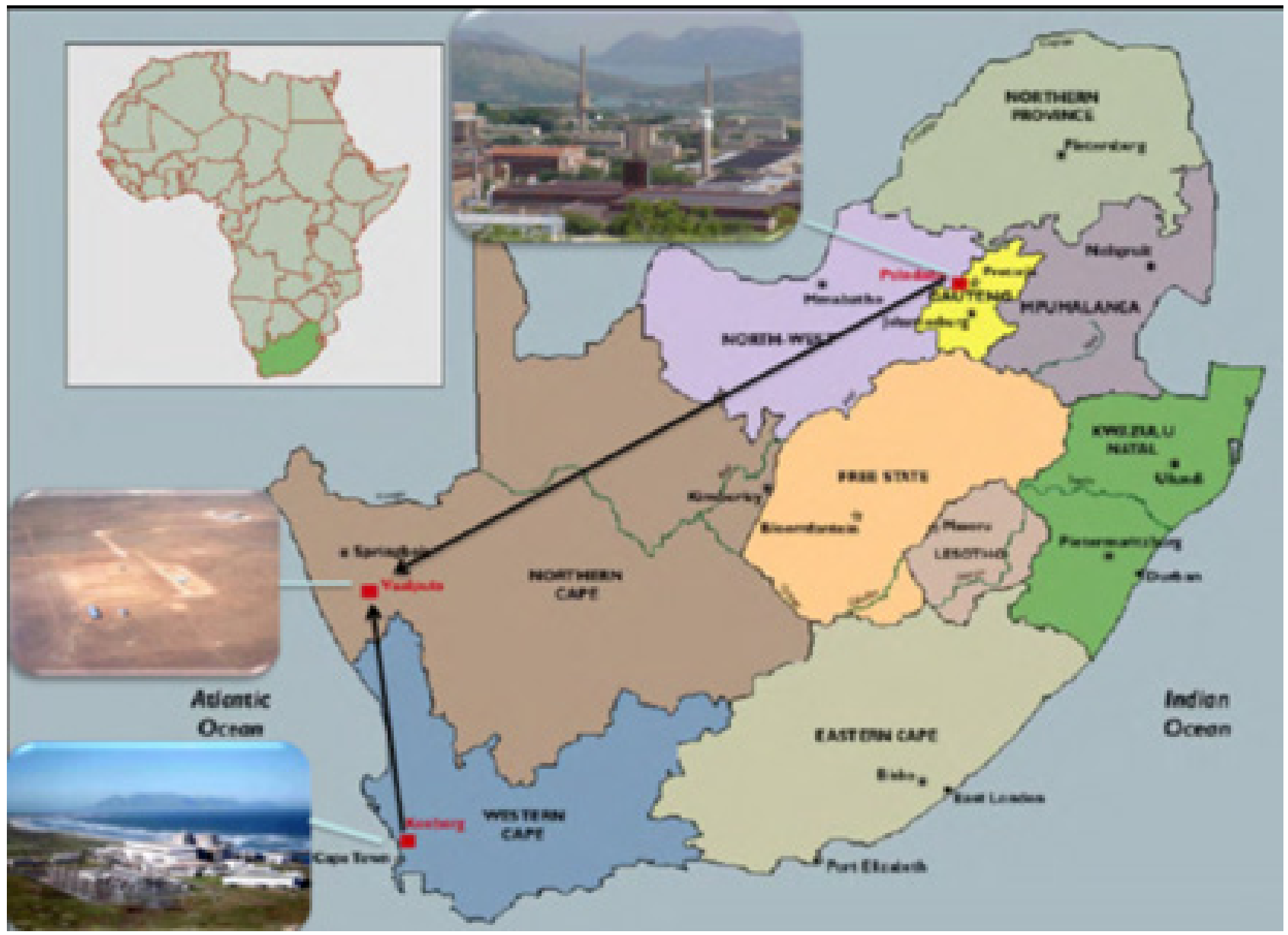

Figure 2. Geographical location of selected nuclear facilities

It is imperative to note that the legislative and regulatory framework for radioactive waste management and disposal is informed by and gives effect to:

- Joint Convention on the Safety of Spent Fuel Management and on the Safety of Radioactive Waste Management [1]

- National Radioactive Waste Disposal Institute Act (NRWDIA) [4]

- Nuclear Energy Act [5]

- RWMP\&S

In order to ensure that radioactive wastes are managed safely, the governance framework makes provision for: An established legislative and regulatory framework, the necessary organisations for implementation and providing oversight of waste management operations and facility development. Independence between the Regulator, Waste Generators and repository operator is the key to ensure that the RSA has an integrated and sustainable approach to ensure that the long term management is executed. RSA's approach to addressing radioactive waste management issues is RWMP\&S which sets a general policy for dealing with all radioactive waste from the nuclear fuel cycle. RWMP\&S developed in consultation with all stakeholders and transparency's principle serves as a national commitment to address radioactive waste management. RWMP\&S puts forward the following hierarchy of waste management options to be followed, where practicable: Avoiding waste and minimisation; reuse, reprocessing and recycling; storage; conditioning and final disposal. Final disposal is regarded as the ultimate step in the radioactive waste management process.

The RWMP\&S establishes the National Committee on Radioactive Waste Management (NCRWM). This committee is constituted by representatives from different state departments. One of the responsibilities of the committee is to evaluate the radioactive waste plans submitted by radioactive waste generators and to provide recommendations to the Minister of Energy.

The RWMP\&S also makes provision for a National Radioactive Waste Management Fund managed by the South African Government to ensure sufficient provision for the long term management of radioactive waste with the principle that the 'Polluter pays'.

The NRWDIA endorsed the establishment of the National Radioactive Waste Disposal Institute (NRWDI) which is a national public entity. The NRWDIA became effective in December 2009. The Institute is mandated to discharge a Ministerial institutional obligation with respect to the management of radioactive waste disposal and related waste. The RSA acceded to the Joint Convention on the Safety of 
Spent Fuel Management and on the Safety of Radioactive Waste Management (Joint Convention) in 2006. One of the objectives of the NRWDI is to fulfil national obligations in respect of the long term management of radioactive waste disposal and related waste management activities as dictated by the Joint Convention.

According to Section 5 of NRWDIA, the Institute must:

(a) Perform any function that may be assigned to it by the Minister in terms of Section 55(2) of the Nuclear Energy Act, in relation to radioactive waste disposal;

(b) Manage, operate and monitor operational radioactive waste disposal facilities, including related storage and predisposal management of radioactive waste at disposal sites;

(c) Investigate the need for any new radioactive waste disposal facilities and site, design and construct such new facilities as may be required;

(d) Conduct research and develop plans for the long-term management of radioactive waste storage and disposal.

\subsection{The Current HLW and UNF Management}

At present nuclear installations in South Africa uses a combination of wet and dry storage for used nuclear fuel. UNF from the KNPS is currently stored in pools on the site as well as in casks designed and constructed for storage of used nuclear fuel. The used nuclear fuel from the SAFARI-1 Research Reactor is initially stored in the reactor pool for at least two years to facilitate cooling of the used fuel prior to it being transferred to an authorised dry storage facility on the Pelindaba site. HLW originated from historical nuclear programme is stored on the same site.

\subsection{The Management Option and Strategies for HLW and UNF}

The RWMS\&P clearly indicates that storage on these sites is not sustainable in the long term and considers the following waste management options for UNF and HLW: Long-term above ground storage on an off-site licensed facility; reprocessing, conditioning and recycling; direct deep geological disposal and transmutation. Regardless of any UNF/HLW management strategy chosen, a Centralized Interim long term off-site Storage Facility (CISF) and Deep Geological Repository (DGR) for final disposal will be required. Like any option chosen for the UNF, the DGR needs to be technically sound, socially acceptable, environmentally responsible and economically feasible. Transmutation requires major investment, two cycles options for the management of UNF can be considered: open cycle and closed cycle.

\section{Open Cycle without Recycling/ Reprocessing}

The fuel will be stored at the reactor site and will be transferred to a centralised off-site storage pending the final decision or, after the transfer to a centralised off-site storage, the UNF will be directly disposed.

\section{Closed Cycle with Recycling/ Reprocessing}

Firstly, the UNF will be stored at the reactor site for a specific period, secondly will be reprocessed and finally the UNF will be disposed or, after the transfer to a centralised off-site storage, the UNF will be reprocessed where the useful material will be reused and the waste will be disposed.

Currently the solid low level and intermediate level waste from KNPS and NECSA are disposed of at the national radioactive waste disposal facility Vaalputs located in the Northern Cape Province (Fig.2). Preliminary investigation in the early $90 \mathrm{~s}$ has indicated that Vaalputs has suitable characteristics that would make this site a favorite candidate to host the CISF and a DGR.

The RSA has addressed the INIR mission's recommendation by drafting a new policy detailing options and strategies for UNF/ HLW management. The document was finalized and in currently under review by the Cabinet of the RSA.

\section{Key Challenges}

One of the lessons learnt from the Fukushima accident was the importance to limit the UNF inventory on-site. On-site storage should only be for cooling purposes of the UNF. The RSA Government has committed to establish and operate a centralized off-site interim storage facility by 2025 and a deep geological repository by 2065 [6]. In addition, centralized off-site interim storage facility will provide South Africa with the flexibility to make an informed decision with regard to fuel cycle strategy (open or closed). Provision must be made for additional waste storage/ disposal due to potential operation of new nuclear power plants as the RSA is considering a new nuclear build programme and the possible long term operation of the KNPS. The Fukushima accident has eroded the confidence of the public in nuclear power and safe radioactive waste management. Hence, to be successful the waste management programme must overcome this negative perception as technical competence is not enough to ensure and instill stakeholder's trust and acceptability. Waste Generators in RSA must still submit their radioactive waste management plans for review and to the NCRWM. This committee will determine the funding strategy and requirements for sustainable long term operation of NRWDI. Funding is required for disposal activities, research and development including investigations into waste management/disposal options. The process of the site's selection for the centralized off-site interim storage facility and deep geological repository must be developed for licensing.

\section{Conclusions}

South Africa has an integrated and extensive national 
radioactive waste management model which considers the different options and strategies to address the long term management of the UNF and HLW as recommended by the INIR. Final disposal is regarded as the ultimate step in the radioactive waste management process. In spite of challenges and irrespective of the fuel strategy chosen, it is inescapable that South Africa needs the following waste management infrastructure namely (i) CISF and (ii) a DGR. Finally, the RSA must develop and implement a comprehensive communication strategy and plan to demystify and decipher the public's fears regarding the management of radioactive waste and to deepen and strengthen stakeholder's acceptance, confidence and trust.

\section{REFERENCES}

[1] Joint Convention on the Safety of Spent Fuel Management and on the Safety of Radioactive Waste Management IAEA, 1997.

[2] Radioactive Waste Management Policy and Strategy for the Republic of South Africa, 2005.

[3] Department of Energy, Media Statement: Nuclear Procurement Process Update, 14 July 2015.

[4] National Radioactive Waste Disposal Institute Act (NRWDIA), Act 53 of 2008.

[5] Nuclear Energy Act, Act No. 46 of 1999.

[6] South African National Report on the Compliance to Obligations under the Joint Convention on Safety of Spent Fuel Management and on the Safety of Radioactive Waste Management, September 2014. 